\title{
Energy cost of ingesting and excreting indigestible material in growing pigs is minimal
}

\author{
Cornelis De LANGE ${ }^{\mathrm{a} *}$, Jaap VAN MiLGEN ${ }^{\mathrm{b}}$, Serge DuboIs $^{\mathrm{b}}$, \\ Jean NOBLET ${ }^{\mathrm{b}}$

\footnotetext{
${ }^{a}$ Department of Animal and Poultry Science, University of Guelph, Guelph, ON, Canada N1G 2W1

b Institut National de la Recherche Agronomique, Unité Mixte de Recherches Systèmes d'Élevage, Nutrition Animale et Humaine, St-Gilles, France
}

(Received 26 January 2006 - Accepted 4 October 2006)

\begin{abstract}
The nutritive value of pig feed ingredients is generally derived from the digestible nutrient supply, while little consideration is given to the impact of indigestible material on nutrient utilization. An experiment was conducted to determine heat production (HP) associated with ingestion and excretion of indigestible material in growing pigs. Five pairs of littermate barrows were assigned to a basal diet (Basal) or to a basal diet mixed with wheat straw in a 4:1 ratio (Straw). The pigs were housed individually in metabolism crates and adjusted to feeding regimes for at least $10 \mathrm{~d}$ prior to measuring components of HP using indirect calorimetry. The dynamics of HP was recorded for $5 \mathrm{~d}$ during the fed state and during a subsequent $24 \mathrm{~h}$ fast. Feeding behavior, physical activity of the animals and N-balance were monitored to associate HP with feeding (HPfeed), activity and energy retention. Mean body weight $(\mathrm{BW})$ of the pigs was similar $(62.1 \mathrm{~kg})$ for both diets. Dry matter intake (1783 vs. $2207 \mathrm{~g} \cdot \mathrm{d}^{-1}$, SE 9) and fecal DM excretion (200 vs. $\left.588 \mathrm{~g} \cdot \mathrm{d}^{-1}, \mathrm{SE} 12\right)$ were higher $(P<0.05)$ in straw fed pigs, while ME intake was similar $\left(2302 \mathrm{vs.} 2359 \mathrm{~kJ} \cdot \mathrm{kg} \mathrm{BW}^{-0.60} \cdot \mathrm{d}^{-1}\right.$; SE 28). Based on the difference method, the digestibility of DM and gross energy in straw was $15.0 \%$ (SE 3.1) and 13.3\% (SE 3.9), respectively. Various aspects of energy utilization (expressed as $\mathrm{kJ} \cdot \mathrm{kg} \mathrm{BW}^{-0.60} \cdot \mathrm{d}^{-1}$; Basal vs. Straw) did not differ $(P>0.10)$ between treatments: total HP $(1374$ vs. 1355; SE 14), fasting HP (762 vs. 747 ; SE 6), activity HP (150 vs. 164; SE 15), HPfeed (452 vs. 444; SE 7), and energy retention (961 vs. 983 , SE 10). The overall energy cost of ingesting and excreting indigestible material in growing pigs appears minimal and could not be identified in this experiment.
\end{abstract}

pig / energy / feces / excretion / heat production

Résumé - Le coût énergétique de l'ingestion et de l'excrétion de l'indigestible est faible chez le porc en croissance. La valeur nutritionnelle des aliments est généralement liée à la quantité de nutriments digestibles et peu d'attention est portée aux effets de la fraction indigestible sur l'utilisation des nutriments. L'objet de l'expérience était donc de quantifier la production de chaleur (HP) liée à l'ingestion et l'excrétion de l'indigestible chez le porc en croissance. Cinq couples de mâles castrés

\footnotetext{
* Corresponding author: cdelange@ uoguelph.ca
} 
ont reçu soit un aliment témoin, soit cet aliment témoin plus de la paille de blé (ratio 4:1). Les porcs étaient maintenus en cages de digestibilité et adaptés à l'aliment pendant 10 jours avant les mesures de HP et ses composantes en chambre respiratoire. La cinétique de HP était mesurée pendant 5 jours sur l'animal nourri et une journée à l'état de jeûne. Le comportement alimentaire, l'activité physique et le bilan d'azote étaient mesurés de façon à quantifier le bilan d'énergie et les effets de l'aliment (HPfeed) et de l'activité physique. Le poids vif (BW) des animaux était comparable pour les deux traitements $(62,1 \mathrm{~kg})$. Les quantités de matière sèche ingérée (2207 vs. $1783 \mathrm{~g}$ par jour, SE 9) et excrétée (588 vs. $200 \mathrm{~g}$ par jour, SE 12) étaient plus élevées $(P<0,01)$ avec l'aliment paille mais les quantités d'EM ingérées étaient identiques (2359 vs. $2302 \mathrm{~kJ}$ par kg BW ${ }^{0.60}$, SE 28). Sur le principe de la méthode par différence, la digestibilité de la matière sèche et de l'énergie de la paille de blé étaient de, respectivement, 15,0 \% (SE 3.1) et 13,3\% (SE 3.9). Les différentes données du bilan énergétique (exprimées par $\mathrm{kg} \mathrm{BW}^{0.60}$; témoin vs. paille) étaient comparables pour les deux traitements : HP totale (1374 vs. $1355 ;$ SE 14), HP à jeun (762 vs. 747 ; SE 6), HP liée à l'activité physique (150 vs. 164 ; SE 15), HPfeed (452 vs. 444; SE 7) et énergie fixée (961 vs. 983 , SE 10). A partir de ces résultats, il apparaît que le coût énergétique de l'ingestion et de l'excrétion de l'indigestible est négligeable chez le porc et n'a pas pu être identifié dans les conditions de l'expérience.

porc / énergie / indigestible / production de chaleur

\section{INTRODUCTION}

The nutritive value of pig feed ingredients is generally derived from the digestible nutrient supply, while little consideration is given to the impact of indigestible material on nutrient and energy utilization $[5,10,16]$. It can be hypothesized that the ingestion and excretion of indigestible material represents an energy cost to pigs. Based on a systematic analysis of energy balances, Emmans [9] and Birkett and de Lange [2,3] suggested that part of heat production (HP) in growing pigs is associated with ingestion and fecal excretion of indigestible nutrients. However, few experiments have been conducted in which the energy costs of ingestion and fecal excretion of indigestible nutrients have been quantified directly in farm animals. To our knowledge, only Müller and Kirchgeßner [20] have obtained a direct estimate of the energy cost of ingestion and excretion of indigestible material in pigs. However, this estimate was established in adult non-gravid sows and the impact of dietary fiber level on HP associated with changes in animal behavior was not considered [14, 22,23]. The objective of this study was to directly determine HP associated with ingestion and excretion of indigestible material in growing pigs. In this study, ground wheat straw was chosen as the source of indigestible nutrients and components of HP were measured dynamically on pigs that were housed individually using indirect calorimetry.

\section{MATERIALS AND METHODS}

\subsection{Experimental design}

Five pairs of littermate barrows, Piétrain $\times$ (Large White $\times$ Landrace) crosses from the Institut National de la Recherche Agronomique (INRA) herd, were selected at approximately $45 \mathrm{~kg}$ body weight (BW). Littermates were assigned to either a barley, wheat and soybean meal based basal diet (Basal) or to the basal diet mixed with wheat straw in a 4:1 ratio (Straw) (Tab. I). The basal diet was formulated to be first limiting in lysine and to contain a standardized ileal digestible lysine to digestible energy ratio of $0.69 \mathrm{~g} \cdot \mathrm{MJ}^{-1}$, which is in excess of lysine requirements for pigs with improved lean tissue growth potentials [16]. Diets were prepared at the feedmill of INRA. The straw was chopped to 
Table I. Ingredient composition and nutrient content of experimental diets.

\begin{tabular}{|c|c|c|}
\hline & Basal & Straw \\
\hline \multicolumn{3}{|l|}{ Ingredients (\%, as fed) } \\
\hline Wheat straw & - & 20.00 \\
\hline Wheat & 37.40 & 29.92 \\
\hline Barley & 37.39 & 29.91 \\
\hline Soybean meal & 18.00 & 14.40 \\
\hline Dicalcium phosphate & 1.20 & 0.96 \\
\hline Calcium carbonate & 1.10 & 0.88 \\
\hline Lysine $\mathrm{HCL}$ & 0.28 & 0.22 \\
\hline Methionine & 0.06 & 0.05 \\
\hline Threonine & 0.09 & 0.07 \\
\hline Tryptophan & 0.03 & 0.03 \\
\hline Cane molasses & 3.50 & 2.80 \\
\hline Salt & 0.45 & 0.36 \\
\hline Vitamins and minerals ${ }^{1}$ & 0.50 & 0.40 \\
\hline \multicolumn{3}{|l|}{ Calculated nutrient content $(\% \text {, as fed })^{2}$} \\
\hline Digestible energy in $\mathrm{MJ} \cdot \mathrm{kg}^{-1}$ & 13.1 & 11.5 \\
\hline Crude Protein $(\mathrm{N} \times 6.25)$ & 17.6 & 14.7 \\
\hline Standardized ileal digestible lysine & 0.90 & 0.72 \\
\hline Calcium & 0.79 & 0.63 \\
\hline Phosphorus & 0.57 & 0.46 \\
\hline \multicolumn{3}{|c|}{ Analyzed nutrient content (\%, dry matter basis) } \\
\hline Dry matter & 87.7 & 88.4 \\
\hline Gross energy in $\mathrm{MJ} \cdot \mathrm{kg}^{-1}$ & 17.96 & 18.07 \\
\hline Organic matter & 94.1 & 94.4 \\
\hline Crude protein $(\mathrm{N} \times 6.25)$ & 18.3 & 14.9 \\
\hline Crude fat & 2.8 & 2.5 \\
\hline Neutral detergent fiber & 13.8 & 30.2 \\
\hline Acid detergent fiber & 5.3 & 16.1 \\
\hline
\end{tabular}

${ }^{1}$ The vitamin-mineral premix contained (g per kg premix) 0.55 retinyl palmitate, 0.0050 cholecalciferol, 4.0 DL- $\alpha$-tocopherol acetate, 0.39 thiamin, 0.80 riboflavin, 0.20 pyridoxine, 0.0040 cobalamin, 3.0 niacin, 2.0 calcium $\delta$-pantothenate, 0.20 folic acid, 0.40 menadione, 100 choline chloride, $16 \mathrm{Zn}$, $0.80 \mathrm{Cu}, 5.7 \mathrm{Mn}, 7.7 \mathrm{Fe}, 0.026 \mathrm{I}, 0.0076 \mathrm{Co}$ and $0.014 \mathrm{Se}$.

${ }^{2}$ Based on ingredient nutrient contents according to INRA \& AFZ [10]. The nutrient supply from wheat straw is ignored, except for the crude protein. Wheat straw contained $91.0 \% \mathrm{DM}$ and on a dry matter basis $5.0 \%$ ash, $4.4 \% \mathrm{CP}, 85.6 \% \mathrm{NDF}, 51.9 \% \mathrm{ADF}$ and $18.80 \mathrm{~kJ}$ per g.

reduce particle length to less than $10 \mathrm{~mm}$ and mixed with the basal diet prior to pelleting.

Pigs were housed individually in metabolism crates and adjusted to feeding regimes for at least $10 \mathrm{~d}$ prior to measuring digestibility and components of heat production (HP) and N-balance in two identical open-circuit respiration units. During adaptation and measurement of energy and N-balances, feeding levels were targeted at $2.4 \mathrm{MJ} \mathrm{DE} \cdot \mathrm{kg} \mathrm{BW}^{-0.60} \cdot \mathrm{d}^{-1}$, 
which is equivalent to approximately 2.3 times maintenance energy requirements for this type of pigs [18]. Feeding levels were related to $\mathrm{kg} \mathrm{BW}^{-0.60}$ to accurately reflect $\mathrm{BW}$ effects on energy expenditure in growing pigs [18]. For establishing feeding levels, available energy supplied from wheat straw was ignored, which meant that pigs on the Straw treatment received $25 \%$ more feed than pigs on the Basal treatment. Feeding levels were adjusted every 2 or $3 \mathrm{~d}$ (d 1, 3 and 5 in each week) based on anticipated mean BW. During the adaptation period, pigs were fed three times daily. Water was freely available from low-pressure nipple drinkers.

Measurements were made in two littermate pigs each week. Therefore, the assignment of pigs to treatments was staggered at weekly intervals and treatments were switched between the two respiration units each week. The mean BW of pigs when placed in the respiration units was $58.7 \pm 3.1 \mathrm{~kg}$.

An authorization to perform an experiment on living animals was given by the French Ministry of Agriculture and Fishery (certificates 4739 and 7704 for Noblet and van Milgen, respectively).

\subsection{Indirect calorimetry and N-balance measurements}

Pigs were maintained individually in one of the two large open-circuit respiration units at INRA [25] for 7-d periods after the adaptation period. Pigs were weighed on the morning of the day they entered the chambers, as well as on the mornings of days seven and eight. In the respiration units, pigs were fed four equally sized meals daily at 0900, 1300, 1700 and $1900 \mathrm{~h}$. The first day served as an adjustment to the new environment and was not considered in the final HP and nutrient balance calculations. On days two to six, measurements of oxygen $\left(\mathrm{O}_{2}\right)$ consumption and production of carbon dioxide $\left(\mathrm{CO}_{2}\right)$, methane and ammonia were made in pigs in the fed state; $\mathrm{O}_{2}$ consumption and $\mathrm{CO}_{2}$ production was measured on day seven in fasting pigs. Changes in gas concentrations were recorded at 10 -second intervals and, combined with physical aspects of gas exchanges (changes in atmospheric pressure, relative humidity, gas extraction rates), were used to calculate daily total HP $[4,25]$. In the respiration units, animal activity (signal of force sensors underneath the metabolic cages) and ingestion of feed (measured using load cells underneath the feeder) were monitored continuously [25], while feces and urine were collected quantitatively and removed once daily for measurement of diet DE and ME content and whole body N-balance [27].

Representative feed, and pooled feces and urine samples (pooled for day one to six during calorimetry and per pig) were analyzed for ash (combustion at $550{ }^{\circ} \mathrm{C}$ ), energy (using an adiabatic bomb calorimeter, IKA, C5000, Staufen, Germany), $\mathrm{CP}(\mathrm{N} \times 6.25)$ and ether extract (in feed only) content according to AOAC [1]. Contents of NDF and ADF were determined according to Van Soest and Wine [28] following treatment of samples with amylase. Digestibility of dry matter, organic matter, NDF and gross energy in the two diets was determined based on the total fecal collection method [17]. The digestibility of these constituents in wheat straw was calculated using the difference method [17]; these calculations were conducted for individual pigs fed the wheat straw containing diet and based on the observed mean digestibility values for the basal diet [7].

Components of HP were estimated according to van Milgen et al. [25, 26] and van Milgen and Noblet [24]. In short, $\mathrm{O}_{2}$ consumption and $\mathrm{CO}_{2}$ patterns were related statistically to animal activity and feed intake to generate estimates of 
HP activity (HPact; kJ per unit of force) and short-term thermic effect of feeding (HPfeed-st; kJ per kg feed intake). Resting HP (HPrest) of pigs in the fed state was calculated as total HP minus HPact and HPfeed-st. Activity-free fasting HP (HPfast) was estimated statistically from estimated asymptotic plateau $\mathrm{O}_{2}$ consumption and $\mathrm{CO}_{2}$ production following a $24 \mathrm{~h}$ fast. The difference between HPrest and HPfast was considered to be the longterm thermic effects of feeding (HPfeed1t), whereas HPfeed was calculated as the sum of HPfeed-st and HPfeed-lt. Energy retention in the pigs' body was calculated as the difference between ME intake and total HP. Based on observed whole body protein deposition, calculated as observed $\mathrm{N}$ retention $\times 6.25$, and the assumed gross energy contents of deposited body protein and body lipid, body lipid deposition was then calculated $[24,25]$. The results concerning HP and energy retention are expressed as $\mathrm{kJ} \cdot \mathrm{kg} \mathrm{BW}^{-0.60} \cdot \mathrm{d}^{-1}$ and are based on averages of five daily values for individual pigs.

\subsection{Statistical analyses}

The mixed models procedure of SAS was used for statistical analyses (version 8.0; SAS Inst. Inc. Cary, NC, USA). Data were subjected to analyses of variance with litter (identical to week of measurement; $n=5)$, dietary treatment $(n=2)$ and either initial BW or ME intake (covariable) as sources of variation, while animals were considered the experimental units. Litter and animal were considered to be random effects.

\section{RESULTS}

Throughout the experiment, the pigs seemed healthy and no abnormalities in animal behavior were observed. All pigs con- sumed their daily feed allowances. However, unlike pigs fed the basal diet, pigs fed the straw containing diet did not eat their feed allowances in three (adaptation period) or four (measurement period) distinct daily meals. Pigs fed the straw based diets also spent $86 \%$ more time eating than pigs fed the basal diet (138 vs. 74 minutes per day; SE 20; $P=0.04$ ). Unfortunately, technical problems occurred during the last day of one of the experimental periods. As a result, HPfast and HPfeed-lt were only measured in four pigs per treatment.

The mean BW was similar $(P>0.10)$ for the two treatments (Tab. II). As intended pigs fed the straw diet consumed $25 \%$ more feed, which was attributed fully to intake of wheat straw, while fecal dry matter excretion was close to three times higher on pigs on the straw treatment $(P<0.001$; Tab. II). Feeding additional straw tended to increase $(P=0.06)$ live body weight gain during measurement of energy expenditure and N-balance, which was associated with increased body lipid deposition and increased live body weight loss during the $24 \mathrm{~h}$ fast $(P<0.05$; Tab. II). The inclusion of wheat straw in the diet did not $(P>0.10)$ alter aspects of $\mathrm{N}$ utilization, except for increased fecal $\mathrm{N}$ excretion $(P<0.002$; Tab. II). Pigs fed the straw containing diet produced $50 \%$ less methane, but because of a high variability this difference was not significant $(P=0.10)$.

The inclusion of straw in the diet reduced $(P<0.001)$ digestibility of dietary dry matter, organic matter, NDF and gross energy, as well as diet DE and ME contents, while it increased $(P<0.05)$ the dietary ME to DE ratio (Tab. III). Based on the difference method, the apparent digestibility of dry matter, organic matter, NDF and gross energy in wheat straw were calculated to be $15.0 \%$ (SE 3.1), 18.0 (SE 1.9), 26.6 (SE 2.3) and 13.3 (SE 3.9), respectively (Tab. III). Using this approach, the digestibility of $\mathrm{N}$ and ash 
Table II. Intake and fecal excretion of dry matter, nitrogen utilization and methane excretion in pigs fed controlled levels of a wheat, barley and soybean meal based basal diet (Basal) or basal diet with additional wheat straw $(\text { Straw })^{1}$.

\begin{tabular}{|c|c|c|c|c|}
\hline Item & Basal & Straw & $\begin{array}{c}\text { Pooled } \\
\text { SEM }\end{array}$ & $P$ value \\
\hline Number of pigs & 5 & 5 & & \\
\hline Average body weight (kg) & 61.5 & 62.4 & 0.8 & 0.49 \\
\hline \multicolumn{5}{|l|}{ Feed dry matter intake } \\
\hline Total $\left(\mathrm{g} \cdot \mathrm{d}^{-1}\right)$ & 1783 & 2207 & 9 & $<0.001$ \\
\hline Total $\left(\mathrm{g} \cdot \mathrm{kg} \mathrm{BW} \mathrm{B}^{-0.60} \cdot \mathrm{d}^{-1}\right)$ & 149.8 & 185.7 & 0.6 & $<0.001$ \\
\hline Basal diet $\left(\mathrm{g} \cdot \mathrm{kg} \mathrm{BW}^{-0.60} \cdot \mathrm{d}^{-1}\right)$ & 149.8 & $147.3^{2}$ & 0.6 & 0.04 \\
\hline Wheat straw $\left(\mathrm{g} \cdot \mathrm{kg} \mathrm{BW} \mathrm{B}^{-0.60} \cdot \mathrm{d}^{-1}\right)$ & - & $38.4^{2}$ & 0.08 & $<0.001$ \\
\hline \multicolumn{5}{|l|}{ Fecal dry matter excretion } \\
\hline in $g \cdot d^{-1}$ & 200 & 588 & 12 & $<0.001$ \\
\hline in $\mathrm{g} \cdot \mathrm{kg} \mathrm{BW} \mathrm{B}^{-0.60} \cdot \mathrm{d}^{-1}$ & 16.0 & 50.2 & 0.3 & $<0.001$ \\
\hline Live body weight gain ( 6 days; $\mathrm{g} \cdot \mathrm{d}^{-1}$ ) & 973 & 1280 & 82 & 0.06 \\
\hline Live body weight loss during $24 \mathrm{~h}$ fast $(\mathrm{kg})$ & 3.1 & 4.6 & 0.4 & 0.05 \\
\hline \multicolumn{5}{|l|}{ Nitrogen $(\mathrm{N})$ balance $\left(\mathrm{g} \cdot \mathrm{d}^{-1}\right)$} \\
\hline $\mathrm{N}$ intake & 51.9 & 51.3 & 0.2 & 0.17 \\
\hline Fecal $\mathrm{N}$ excretion & 6.4 & 13.1 & 0.4 & $<0.002$ \\
\hline Urinary $\mathrm{N}$ excretion & 19.3 & 14.5 & 1.7 & 0.15 \\
\hline Ammonia $\mathrm{N}$ loss $s^{3}$ & 0.31 & 0.39 & 0.1 & 0.52 \\
\hline $\mathrm{N}$ retention & 25.9 & 23.3 & 1.2 & 0.23 \\
\hline Body protein deposition $(\mathrm{N} \times 6.25)$ & 161 & 145 & 7.2 & 0.23 \\
\hline Methane excretion $\left(L \cdot d^{-1}\right)$ & 4.4 & 1.9 & 0.6 & 0.10 \\
\hline Body lipid deposition $\left(\mathrm{g} \cdot \mathrm{d}^{-1}\right)$ & 191 & 211 & 4.7 & 0.04 \\
\hline
\end{tabular}

${ }^{1}$ Except for average body weight (BW), either metabolizable energy intake $\left(\mathrm{kJ}^{\prime} \cdot \mathrm{kg} \mathrm{BW}^{-0.60}\right)$ for all measurements expressed per $\mathrm{kg} \mathrm{BW}{ }^{-0.60}$, or initial BW was used as a covariable in the statistical analyses.

${ }^{2}$ Calculated from total feed intake, assuming that basal diet and wheat straw contributed 79.3 and $20.7 \%$ to DM content of the straw containing diet, respectively.

${ }^{3}$ Sum of ammonia recovered in condensates and air removed from the respiration units.

in straw was calculated to be negative, reflecting increases in fecal excretion of about $3.2 \mathrm{~g} \mathrm{~N}$ and $6 \mathrm{~g}$ ash per $100 \mathrm{~g}$ additional dry matter intake from straw. Expressed per kg of dry matter intake or per MJ ME intake, the inclusion of straw in the diet reduced HPfeed-st $(P<0.05)$. In contrast, the addition of straw to the diet did not influence HPfeed-lt per kg of dry matter intake $(P=0.22)$ and increased
HPfeed-lt $(P=0.01)$ per MJ ME intake. As a result, HPfeed was reduced per $\mathrm{kg}$ of dry matter intake $(P=0.02)$ but was not changed per MJ ME intake $(P=0.92)$ with the addition of straw to the diet.

When the slight numerical difference in ME intake between the two treatments was considered and energy expenditure was expressed per $\mathrm{kg} \mathrm{BW}{ }^{0.60}$, the inclusion of wheat straw in the diet did not influence 
Table III. Diet digestible energy (DE) and metabolizable energy (ME) contents, as well as thermal effects of feeding in pigs fed controlled levels of a wheat, barley and soybean meal based basal diet (Basal) or basal diet with additional wheat straw (Straw) ${ }^{1}$.

\begin{tabular}{|c|c|c|c|c|}
\hline Item & Basal & Straw & $\begin{array}{c}\text { Pooled } \\
\text { SEM }\end{array}$ & $P$ value \\
\hline Number of pigs & 5 & 5 & & \\
\hline Diet dry matter digestibility (\%) & 88.8 & 73.3 & 0.7 & $<0.001$ \\
\hline Diet organic matter digestibility (\%) & 90.5 & 75.4 & 0.5 & $<0.001$ \\
\hline Diet NDF digestibility $(\%)$ & 65.7 & 44.6 & 1.6 & $<0.001$ \\
\hline Diet gross energy digestibility (\%) & 88.9 & 72.6 & 0.7 & $<0.001$ \\
\hline Diet DE content (MJ.kg dry matter ${ }^{-1}$ ) & 15.99 & 13.09 & 0.15 & $<0.001$ \\
\hline Diet ME content $\left(\mathrm{MJ} \cdot \mathrm{kg}\right.$ dry matter $\left.{ }^{-1}\right)$ & 15.44 & 12.70 & 0.13 & $<0.001$ \\
\hline Diet ME / diet DE & 0.965 & 0.970 & 0.001 & 0.05 \\
\hline \multicolumn{5}{|l|}{ Thermal effects of feeding ${ }^{2}$} \\
\hline Short term, in kJ.kg dry matter intake ${ }^{-1}$ & 1233 & 731 & 40 & 0.01 \\
\hline in $\mathrm{kJ} \cdot \mathrm{MJ} M E$ intake $^{-1}$ & 80 & 59 & 3.2 & 0.05 \\
\hline Long term ${ }^{3}$, in $\mathrm{kJ} \cdot \mathrm{kg}$ dry matter intake $\mathrm{e}^{-1}$ & 1600 & 1549 & 18 & 0.21 \\
\hline in $\mathrm{kJ} \cdot \mathrm{MJ}$ ME intake ${ }^{-1}$ & 103 & 123 & 1.3 & 0.01 \\
\hline Total $^{3}$, in $\mathrm{kJ} \cdot \mathrm{kg}$ dry matter intake ${ }^{-1}$ & 2833 & 2280 & 46 & 0.02 \\
\hline in $\mathrm{kJ} \cdot \mathrm{MJ} M E$ intake $^{-1}$ & 183 & 182 & 3.3 & 0.92 \\
\hline
\end{tabular}

total HP, HPfast, HPact, HPrest and energy retention in the pigs $(P>0.10)($ Tab. IV). Per kg BW ${ }^{0.60}$, HPfeed was not influenced by dietary treatment while HPfeed-st and HPfeed-lt were reduced and increased $(P<$ $0.05)$, respectively, with the inclusion of straw in the diet (Tab. IV).

In pigs fed the basal diet, a distinct increase in HP was observed over a short time period during the night. This phenomenon, previously referred to as a ghost effect [24], was not related to changes in animal or activity or feeding behavior. The contribution of ghost HP to total HP is nevertheless small, about $1 \%$ of total HP in pigs fed the basal diet, while it was not different from zero in pigs fed the straw containing diet (Tab. IV). The respiratory quo- tient during both the fed and fasted state were not influenced by dietary treatment either $(P>0.60)$ (Tab. IV).

\section{DISCUSSION}

Various researchers have observed negative correlations between dietary fiber levels and the utilization of ME for body energy retention in growing pigs $[11,12,17]$, implying increased HP associated with increasing levels of fiber and, as a result, with intake of indigestible material. In contrast, in other studies no negative effects of including a fiber source in the diet on the utilization of ME for body energy retention were observed [14, 21, 23]. Variation 
Table IV. Digestible energy (DE) and metabolizable energy (ME) intake, as well as component of energy expenditure and respiratory quotients in pigs fed controlled levels of a wheat, barley and soybean meal based basal diet (Basal) or basal diet with additional wheat straw (Straw) ${ }^{1}$.

\begin{tabular}{lcccc}
\hline Item $\left(\mathrm{kJ} \cdot \mathrm{kg} \mathrm{BW}^{-0.60} \cdot \mathrm{d}^{-1}\right)$ & Basal & Straw & $\begin{array}{c}\text { pooled } \\
\text { SEM }\end{array}$ & $P$ value \\
\hline Number of pigs & 5 & 5 & & \\
DE intake & 2385 & 2432 & 31 & 0.35 \\
ME intake & 2302 & 2359 & 28 & 0.22 \\
Total heat production, fed state & 1374 & 1355 & 14 & 0.47 \\
$\quad$ Components of heat production & & & & \\
$\quad$ Fasting & 762 & 747 & 6 & 0.23 \\
$\quad$ Activity, fed state & 150 & 164 & 15 & 0.59 \\
$\quad$ Resting, fed state & 983 & 1022 & 12 & 0.12 \\
$\quad$ Thermal effects of feeding & & & & \\
$\quad$ Short term & 224 & 161 & 13 & 0.05 \\
$\quad$ Long term & & 287 & 2 & 0.006 \\
$\quad$ Total & & 444 & 7 & 0.54 \\
$\quad$ Ghost, fed state & 452 & 2 & 1 & 0.01 \\
Energy retention, fed state & 14 & & & \\
$\quad$ Total & & 983 & 10 & 0.29 \\
$\quad$ As body protein & 961 & 293 & 17 & 0.58 \\
$\quad$ As body lipid & 310 & 693 & 15 & 0.18 \\
Respiratory quotient & 653 & & & \\
$\quad$ Fed state & 1.11 & 1.10 & 0.02 & 0.74 \\
$\quad$ Fasted state & & 0.82 & 0.01 & 0.60 \\
\hline
\end{tabular}

${ }^{1}$ Except for DE and ME intake, ME intake $\left(\mathrm{kJ} \cdot \mathrm{kg} \mathrm{BW}^{-0.60} \cdot \mathrm{d}^{-1}\right)$ was used as covariable in the statistical analyses.

${ }^{2}$ Based on four pigs per treatment.

in observed relationships between dietary fiber levels and HP or energy utilization may be attributed to confounding effects of dietary fiber source and level on energy cost of feed ingestion and fecal excretion, HP associated with animal activity, enzymatic and fermentative digestion of energy yielding nutrients, HP production in visceral organs, the relatively low biochemical efficiency of using energy derived from fermentable fiber for body energy retention in growing pigs, and experimental conditions $[3,14,22,30]$. For example, Rijnen et al. [22] observed that the source of fermentable fiber influenced the energetic efficiency of utilizing ME intake for body energy retention in group housed pigs, which appeared related to effects of fermentable fiber source on animal activity. This confounding of effects may be addressed by assigning energy or nutrient needs to each of the energy demanding processes that are associated with feed ingestion and nutrient utilization, and by establishing causal relationships between diet characteristics and these energy demanding processes. Based 
on a mathematical representation of energy demanding processes that are associated with nutrient utilization in growing pigs, Birkett and de Lange [3], estimated the direct cost of ingestion and excretion of indigestible nutrients at $1.5 \mathrm{MJ} \mathrm{ME}$ per $\mathrm{kg}$ of fecal dry matter excretion. Based on observed ME intakes and fecal dry matter excretion in the current study, this estimated energy cost represents 1.0 and $3.1 \%$ of ME intake for the Basal and Straw treatment, respectively. This estimate, however, was based on only one study involving adult sows [20] and required verification.

In the current study, the difference in feed intake between the two dietary treatments could be attributed fully to the intake of wheat straw (Tab. II). Therefore, the current study allowed us to associate feeding straw with direct measurement of total HP, HPfeed-st and indirect measurement HPfeed-lt in growing pigs, as well as other components of energy expenditure.

The low digestibility of dry matter, organic material, NDF and energy in wheat straw (Tab. III) is consistent with previous observations $[5,20]$ and indicates that the addition of straw to the diet is an effective means to supply indigestible bulk to pigs. The inclusion of wheat straw in the diet increased the dietary ME to DE ratio (Tab. III) and numerically reduced urinary energy losses and methane energy losses (Tab. II), resulting in a calculated ME content of wheat straw (about $2.9 \mathrm{MJ} \cdot \mathrm{kg}^{-1}$ ) that exceeded the calculated DE content (about $2.5 \mathrm{MJ} \cdot \mathrm{kg}^{-1}$ ). The discrepancy between DE and ME contents of wheat straw, as well as the calculated negative digestibility of $\mathrm{N}$ and ash in wheat straw may be attributed to experimental errors, which can have substantial impact on values determined for low inclusion level feed ingredients and when using the difference method [7]. It also raises some concern about the lack of additivity of nutritive values among ingredients when fibrous ingredients are included in the diet [14].
Feeding straw did not influence aspects of $\mathrm{N}$ utilization, other than fecal excretion of $\mathrm{N}$ (Tab. II). The latter indicated that the limited amount of $\mathrm{N}$ supplied from straw was essentially not digested by the pigs, and that the addition of indigestible material depressed digestibility of $\mathrm{N}$ in the basal diet or increased fecal endogenous nitrogen losses, either directly or via the incorporation of endogenous nitrogen losses into microbial protein. The likely increase in fecal excretion of microbial mass, as a result of feeding straw [6], was consistent with the fermentative degradation of some of the NDF supplied with wheat straw. The addition of straw to the diet tended to reduce methane losses from the pigs. Possibly, indigestible bulk reduces enteric fermentation by methanogenic bacteria [29] or some of the methane generated during hindgut fermentation is adsorbed by fecal material in pigs fed straw based diets. In a previous study, the inclusion of straw in the diet did not influence methane losses from adult sows [20]. Clearly, methane losses from pigs are better related to the intake of fermentable fiber than to indigestible bulk [13, 19, 21].

The observed increase in live body weight gain during the fed state, as well as the higher live body weight loss during the $24 \mathrm{~h}$ fast, when straw was included in the diet largely reflects diet effects on gut fill. The inclusion of fiber in the diet of pigs will increase gut fill during the fed state [21], and, as a result, increase fecal mass excretion during fasting. Empty body weight gain was unlikely influenced by the inclusion of straw in the diet, as indicated by lack of treatment effects on body protein deposition, body energy retention, and the small treatment effect on body lipid deposition (Tab. IV).

Values for components of HP in pigs fed the basal diet were very similar to those obtained in previous studies conducted under similar conditions $[8,14,24]$. Interpolation between two levels of ME intake 
applied in a previous study [8] (2053 and $2543 \mathrm{~kJ} \cdot \mathrm{kg} \mathrm{BW}^{-0.60} \cdot \mathrm{d}^{-1}$ ) to an ME intake level of $2300 \mathrm{~kJ} \cdot \mathrm{kg} \mathrm{BW}^{-0.60} \cdot \mathrm{d}^{-1}$ yields estimates for total HP, HPfast, HPact, HPrest and HPfeed of 1333, 687, 190, 955 and $446 \mathrm{~kJ} \cdot \mathrm{kg} \mathrm{BW}^{-0.60} \cdot \mathrm{d}^{-1}$, respectively, which are similar to the values for pigs fed the basal diet in the current study (Tab. IV). The respiratory coefficients for pigs during the fed and fasted state are similar to previous observations as well $[8,26]$. In an anabolic state with lipogenesis the respiratory coefficient is typically greater than 1.0, while values below 1.0 for pigs during the $24 \mathrm{~h}$ fast indicates that nutrients other than carbohydrates are the main source of energy in fasting pigs [27].

In the current experiment, no effect of feeding wheat straw on HPact was observed, which was in agreement with Le Goff et al. [14]. The observations that pigs fed the straw containing diet spent more time eating and had a lower rate of feed intake than pigs fed the basal diet (16 vs. $24 \mathrm{~g} \cdot \mathrm{min}^{-1}$ ) were not consistent with previous observations in which pigs were fed corn bran as an additional source of fiber [14]. In the study of Le Goff et al. [14] that was conducted under similar conditions, finishing pigs at approximately $76 \mathrm{~kg} \mathrm{BW}$ and consuming 1940 and $2140 \mathrm{~g}$ of a low and high fiber diet, respectively, spent $68 \mathrm{~min} \cdot \mathrm{d}^{-1}$ eating. These combined observations imply that the eating rate of pigs is influenced by the source of dietary fiber and that pigs that spend more time eating may not necessarily spend less time involved in other activities. In order to impact HPact, pig diets may be varied in fermentable fiber content and source, and pigs may be group-housed in larger pens as observed by Rijnen et al. [22].

Even though pigs fed the straw containing diet spent more time eating than pigs fed the basal diet, there was no effect of dietary treatment on total HP and HPfeed, expressed per kg BW ${ }^{0.60}$. Apparently, processes associated with digestion, absorption and metabolism of absorbed nutrients, rather than feed ingestion per se, are the main contributors to thermal effects of feeding. This observation is consistent with the substantial contribution of digestive organs to total HP in growing pigs and the close association between nutrient absorption and HP in portal vein drained visceral organs [30]. For this reason, HPfeed is better related to ME intake or intake of digestible nutrients, rather than dry matter intake (Tab. II) [2]. The observation that HPfeed-st was reduced, while HPfeed-lt was increased, with the inclusion of wheat straw in the diet (Tabs. III, IV) is somewhat difficult to explain, but is consistent with previous observations obtained under similar conditions by Le Goff et al. [14] This apparent inconsistency may be related to the nature of the data and the mathematical procedures that were used to establish HPrest. As mentioned earlier, pigs fed the straw containing diet did not consume their feed in distinct meals. This may have contributed to the increased estimates of resting $\mathrm{O}_{2}$ consumption and $\mathrm{CO}_{2}$ production, and thus to an (numerical) increase in HPrest relative to pigs fed the basal diet (Tab. IV). Such a bias would result in an underestimation of HPfeed-st and an overestimation of HPfeed-lt. It is possible, however, that increased microbial fermentation, as a result of feeding wheat straw, is reflected more in HPfeed-lt than HPfeedst, and that an increased rate of passage in the small intestine, caused by feeding additional fiber [19] reduces HPfeed-st.

In this study, the inclusion of wheat straw in the diet increased body lipid deposition daily (Tab. III). This increase in lipid deposition was associated with the numerical reduction in body protein deposition and numerical increase in daily ME intake. When observations were corrected statistically for differences in ME intake between treatments and expressed per $\mathrm{kg} \mathrm{BW}^{0.60}$, this treatment effect on body lipid deposition was no longer apparent, 
which indicates that the inclusion of wheat straw in the diet does not affect body lipid deposition in growing pigs. This observation was in contrast to results from a previous study [20]. These researchers observed a linear reduction in body energy retention in adult sows of $0.08 \mathrm{~kJ}$ per $\mathrm{kJ}$ addition gross energy intake from barley straw, at a digestibility of energy in barley straw of $13 \%$. These differences in observed body lipid deposition response may be attributed to differences in the physiological state of the pig. For example, in the study of Müller and Kirchgeßner [20], the feeding level was close to maintenance energy requirements, whereas pigs were fed at approximately 2.5 times maintenance energy requirements in the current study. The latter likely reduced the retention time of indigested feed in the gastro-intestinal tract of growing pigs, relative to that in adult sows [15,17]. In the current study, no impact of feeding additional wheat straw on total HP, HPfeed and body energy retention was observed. This implies that HP associated with the ingestion and excretion of indigestible material in growing pigs is not significantly different from 0 , or compensated with slight reductions in other components of HP.

\section{CONCLUSION}

The overall energy cost of ingesting and excreting indigestible material in growing pigs appears minimal, statistically not different from 0 , and lower than previous estimates derived from observations in adult sows (1.5 MJ ME per kg of fecal dry matter excretion) $[3,20]$.

\section{ACKNOWLEDGEMENTS}

We wish to thank Alfred Roger and Pascal Bodinier at the Animal Metabolism Research Unit and the Nutrition Laboratory at
INRA-St-Gilles for their assistance in animal management and chemical analyses. Financial support from INRA for the sabbatical leave of C. de Lange at INRA-St-Gilles is gratefully acknowledged.

\section{REFERENCES}

[1] AOAC, Official Methods of Analyses of the Association of Official Analytical Chemists, in: Herlich K. (Ed.), AOAC International, Arlington, USA, 1990.

[2] Birkett S.H., de Lange C.F.M., A computational framework for a nutrient flow representation of energy utilization by growing mono-gastric animals, Brit. J. Nutr. 86 (2001) 661-674.

[3] Birkett S.H., de Lange C.F.M., Calibration of a nutrient flow model of energy utilization by growing pigs, Brit. J. Nutr. 86 (2001) 675-689.

[4] Brouwer E., Report of sub-committee on constants and factors, in: Blaxter K.L. (Ed.), Energy Metabolism, Proceedings of the 3rd Symposium, European Association for Animal Production, Academic Press, London, UK, 1965, pp. 441-443.

[5] CVB, Centraal Veevoeder Bureau, Veevoedertabel (Table of Feeding Value of Animal Feed Ingredients), Centraal Veevoeder Bureau, Lelystad, The Netherlands, 2003.

[6] de Lange C.F.M., Sauer W.C., Mosenthin R., Souffrant W.B., The effect of feeding different protein-free diets on the recovery and amino acid composition of endogenous protein in ileal digesta collected from the distal ileum and feces in pigs, J. Anim. Sci. 67 (1989) 746-754.

[7] de Lange C.F.M., Gabert V.M., Patience J.F., Gillis D., Digestible energy contents and apparent ileal amino acid digestibilities in regular or partial mechanically dehulled canola meal samples fed to growing pigs, Can. J. Anim. Sci. 78 (1998) 641-648.

[8] de Lange C., van Milgen J., Noblet J., Dubois S., Birkett S., Previous feeding level influences plateau heat production following a $24 \mathrm{~h}$ fast in growing pigs, Anim. Sci. (2006) in press.

[9] Emmans G.C., Effective energy: A concept of energy utilization applied across species, Brit. J. Nutr. 71 (1994) 801-821. 
[10] INRA-AFZ, Tables of composition and nutritional value of feed materials, in: Sauvant D., Perez J.-M., Tran G. (Eds.), Wageningen Academic Publishers (the Netherlands) \& INRA (Paris, France), 2004.

[11] Just A., The net energy value of balanced diets for growing pigs, Livest. Prod. Sci. 8 (1982) 541-555.

[12] Just A., Jorgensen H., Fernandez J.A., The net energy value of diets for growth in pigs in relation to the fermentative processes in the digestive tract and the site of absorption of the nutrients, Livest. Prod. Sci. 10 (1983) 171-186.

[13] Kirchgeßner M., Kreuzer M., Müller H.L., Windisch W., Release of methane and carbon dioxide by the pig, Agribiol. Res. 44 (1991) 103-113.

[14] Le Goff G., Dubois S., van Milgen J., Noblet J., Influence of dietary fibre level on digestive and metabolic utilisation of energy in growing and finishing pigs, Anim. Res. 51 (2002) 245-259.

[15] Le Goff G., Noblet J., Comparative total tract digestibility of dietary energy and nutrients in growing pigs and adult sows, J. Anim. Sci. 79 (2001) 2418-2427.

[16] NRC, National Research Council, Nutrient Requirements of Swine (10th ed.), National Academic Press, Washington, USA, 1998.

[17] Noblet J., Fortune H., Shi X.S., Dubois S., Prediction of net energy values of feeds for growing pigs, J. Anim. Sci. 72 (1994) 344-354.

[18] Noblet J., Karege C., Dubois S., van Milgen J., Metabolic utilization of energy and maintenance requirements in growing pigs: effects of sex and genotype, J. Anim. Sci. 77 (1999) 1208-1216.

[19] Noblet J., Le Goff G., Effect of dietary fibre on the energy value of feeds for pigs, Anim. Feed. Sci. Technol. 90 (2001) 35-52.

[20] Müller H., Kirchgeßner M., Effect of straw and cellulose on heat production and energy utilization in pigs, in: Eckern A., Sundstol F. (Eds.), Energy Metabolism of Farm Animals, Proceedings of the Ninth Symposium, European Association for Animal Production, publication No. 29, 1984, pp. 229-232.
[21] Rijnen M.M.J.A., Energetic utilization of dietary fiber in pigs, Ph.D. Thesis, Wageningen University, Wageningen Institute of Animal Sciences, Wageningen, The Netherlands, 2003.

[22] Rijnen M.W.J.A., Verstegen M.W.A. Heetkamp M.J.W., Schrama J.W., Effects of two different fermentable carbohydrates on activity and heat production in group-housed pigs, J. Anim. Sci. 81 (2003) 1210-1219.

[23] Schrama J.W., Verstegen M.W.A., Verboeket P.H.J., Schutte J.B., Haaksma J., Energy metabolism in relation to physical activity in growing pigs as affected by type of dietary carbohydrate, J. Anim. Sci. 74 (1996) 2220-2225.

[24] van Milgen J., Noblet J., Modelling energy expenditure in pigs, in: McNamara J.P., France J., Beever D. (Eds.), Modelling Nutrient Utilization in Farm Animals, CABI Publishing, London, UK, 2000, pp. 103-114.

[25] van Milgen J., Noblet J., Dubois S., Bernier J.F., Dynamic aspects of oxygen consumption and carbon dioxide production in swine, Brit. J. Nutr. 78 (1997) 397-410.

[26] van Milgen J., Bernier J.F., Lecozler Y., Dubois S., Noblet J., Major determinants of fasting heat production and energetic cost of activity in growing pigs of different body weight and breed/castration combination, Brit. J. Nutr. 79 (1998) 1-9.

[27] van Milgen J., Noblet J., Dubois S., Energetic efficiency of starch, protein and lipid utilization in growing pigs, J. Nutr. 131 (2001) 1309-1318.

[28] Van Soest P.J., Wine R.H., Use of detergents in the analysis of fibrous feeds. IV. Determination of plant cell-wall constituents, J. AOAC 50 (1967) 50-55.

[29] van Soest P.J., Nutritional ecology of the ruminant, O\&B Books Inc, Corvallis, Oregon, 1982, 374 p.

[30] Yen J.-T., Oxygen consumption and energy fluxes of porcine splanchnic tissues, in: Laplace J.-P., Fevrier C., Barbeau A. (Eds.), Digestive Physiology in Pigs, Proceedings 7th International Symposium on Digestive Physiology in Pigs, European Association for Animal Production, Publication No. 88, 1997, pp. 260-269. 